\begin{tabular}{|c|c|c|}
\hline 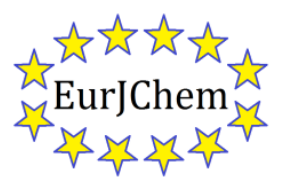 & $\begin{array}{c}\text { European Journal of Chemistry } \\
\text { Journal homepage: } \underline{\text { www.eurjchem.com }}\end{array}$ & 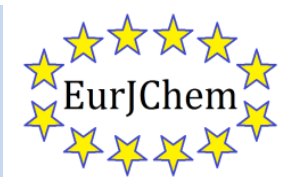 \\
\hline
\end{tabular}

\title{
Synthesis, spectroscopic and thermal characterization of quinoxaline metal complexes
}

\author{
Mohamed Ahmed Badawya, Gehad Genidy Mohameda,*, Mohamed Mohamed Omara, \\ Mamdouh Mohammed Nassarb and Ahmed Badr Kamel ${ }^{\mathrm{a}}$ \\ a Chemistry Department, Faculty of Science, Cairo University, Giza, EG-12613, Egypt \\ ${ }^{b}$ Insecticides Department, Faculty of Science, Cairo University, Giza, EG-12613, Egypt \\ *Corresponding author at: Chemistry Department, Faculty of Science, Cairo University, Giza, EG-12613, Egypt. Tel.: +2.02.35676625; fax: +2.02.35728843. \\ E-mail address: ggenidy68@hotmail.com (G.G. Mohamed).
}

\section{ARTICLE INFORMATION}

Received: 19 May 2010

Received in revised form: 13 August 2010

Accepted: 18 September 2010

Online: 31 December 2010

\section{KEYWORDS}

\section{Quinoxaline}

Transition metal complexes

Spectroscopy

Thermal analyses

DTA/TG

Biological activity

\section{Introduction}

Quinoxaline structure is recognized in a growing number of naturally occurring compounds such as riboflavin (vitamin B2), flavoenzymes, molybdopterines and antibiotics of Streptomyces [1]. Quinoxalines are an important class of nitrogencontaining heterocycles with a variety of biological activities, specifically as AMPA/GlyN receptor antagonists [2,3], angiotensin II receptor antagonists [4,5], anticancer agents [68], antiinfection agents $[9,10]$ and immunomodulating agents [11]. Metal complexes of quinoxaline derivatives have received attention because of their potential metal binding properties and promising applicabilities [12]. Importance was hence given to studying these systems [13-16].

The study of quinoxaline derivatives has become of much interest in recent years due to their antibacterial, antiviral, anticancer, antifungal, antihelminthes and insecticidal activities [17]. In particular, the di- $N$-oxide derivatives of quinoxaline show a dramatically increase of the diversity of biological properties. For example, some of these organic derivatives have shown hypoxia-selective citotoxicity and they could be potentially useful for the treatment of solid tumors. Besides, some derivatives have presented excellent $M$. tuberculosis growth inhibition values, leading generally the lack of the two $N$-oxide groups to the loss of the antimycobacterial activity $[18,19]$. As an effort to improve bioavailability and pharmacological and toxicological properties of quinoxaline $N^{1}, N^{4}$-dioxide derivatives, many authors focused their research on the synthesis, characterization and biological evaluation of a large amount of metal complexes with this family of organic compounds [20-25]. These studies lead to several complexes with higher pharmacological activity than the free ligands, especially iron complexes bearing anti-Mycobacterium tuberculosis activity.

In view of the importance of such quinoxalines, we describe here the coordination behaviour of organic ligand derived from 3-(2-oxo-2-p-tolylethyl)quinoxalin-2(1H)-one (HL) towards some transition elements (Mn(II), Fe(III), Co(II), Ni(II), Cu(II) and $\mathrm{Zn}(\mathrm{II})$ ). The $\mathrm{N}$ and $\mathrm{O}$ coordination sites are helpful as they will do a cavity around the metal ions and hence they can be used as analytical reagents for determination of metal ions. The structure of the studied complexes is elucidated using elemental analyses, IR, ${ }^{1} \mathrm{H}$ NMR, solid reflectance, magnetic moment, molar conductance, and thermal analyses measurements. The biological activity of the parent organic ligand and its metal complexes are reported. The structure of the ligand under investigation is given in Figure 1.<smiles>Cc1ccc(C(=O)Cc2nc3ccccc3[nH]c2=O)cc1</smiles>

Figure 1. Structure of HL ligand. 


\section{Experimental}

\subsection{Instrumentation}

The molar conductance of solid chelates in DMF was measured using Sybron-Barnstead conductometer (MeterPM.6, $E=3406$ ). Infrared spectra were recorded on a PerkinElmer FT-IR type 1650 spectrophotometer in wavenumber region 4000-400 $\mathrm{cm}^{-1}$. The spectra were recorded as $\mathrm{KBr}$ pellets. Microanalysis for carbon, hydrogen, nitrogen, and chloride were carried out at the Microanalytical centers, Cairo University, using a Perkin-Elmer CHN 2400. The solid reflectance spectra were measured on a Shimadzu 3101pc spectrophotometer. The molar magnetic susceptibility was measured on powdered samples using the Faraday method. The diamagnetic corrections were made by Pascal's constant and $\mathrm{Hg}\left[\mathrm{Co}(\mathrm{SCN})_{4}\right]$ was used as a calibrant. The mass spectrum was recorded by the EI technique at $70 \mathrm{eV}$ using MS-5988 GSMS Hewlett-Packard instrument. The ${ }^{1} \mathrm{H}$ NMR spectra were recorded using $300 \mathrm{MHz}$ Varian-Oxford Mercury. The deuterated solvent used was dimethylsulphoxide (DMSO) and the spectra extended from 0 to $15 \mathrm{ppm}$. The thermal analyses (TG, DTG and DTA) were carried out in dynamic nitrogen atmosphere $(20 \mathrm{~mL} / \mathrm{min})$ with a heating rate of $10{ }^{\circ} \mathrm{C} / \mathrm{min}$ using Shimadzu TG-60H and DTA-60H thermal analyzers.

\subsection{Materials and reagents}

The chemicals used included $\mathrm{CuCl}_{2} .2 \mathrm{H}_{2} \mathrm{O}$ (Sigma), $\mathrm{CoCl}_{2} \cdot 6 \mathrm{H}_{2} \mathrm{O}$ and $\mathrm{NiCl}_{2} \cdot 6 \mathrm{H}_{2} \mathrm{O}$ (BDH); $\mathrm{MnCl}_{2}$ (Sigma), $\mathrm{ZnCl}_{2} \cdot 2 \mathrm{H}_{2} \mathrm{O}$ (Ubichem) and $\mathrm{FeCl}_{3} .6 \mathrm{H}_{2} \mathrm{O}$ (Prolabo). Organic solvents (spectroscopic pure from BDH) used included absolute ethyl alcohol, diethylether and dimethylformamide (DMF). Hydrogen peroxide and sodium chloride, sodium carbonate and sodium hydroxide (A.R.) were used. Hydrochloric and nitric acids (Merck) were used.

\subsection{Solutions}

Fresh stock solution of $5 \times 10^{-4} \mathrm{M}$ ligand was prepared by dissolving the accurately weighed amount of HL $(0.139 \mathrm{~g} / \mathrm{L})$ in the appropriate volume of absolute ethanol. $5 \times 10^{-4} \mathrm{M}$ Stock solutions of the metal salts (Co(II) $(0.119 \mathrm{~g} / \mathrm{L}), \mathrm{Cu}(\mathrm{II})(0.085$ g/L), Fe(III) (0.117 g/L), Mn(II) (0.117 g/L), Ni(II) (0.119 g/L) and $\mathrm{Zn}(\mathrm{II})(0.086 \mathrm{~g} / \mathrm{L})$ ) were prepared by dissolving the accurately weighed amounts in the appropriate volume of deionized water. The metal salt solutions were standardized by the recommended procedures [26]. Dilute solutions of the metal ions and organic ligand under study were prepared by accurate dilution. 1.0 N Stock sodium hydroxide solution was prepared by dissolution $4.0 \mathrm{~g}$ in $100 \mathrm{~mL}$ bidistilled water and $0.2 \mathrm{~N}$ solution was prepared by accurate dilution and used for $\mathrm{pH}$ adjustment. Mixture of $0.04 \mathrm{M}$ phosphoric, acetic and boric acids was prepared to obtain universal buffer solutions of the required $\mathrm{pH}$ values from $2-13$. The $\mathrm{pH}$ was adjusted by adding $0.2 \mathrm{~N} \mathrm{NaOH}$ solution to $100 \mathrm{~mL}$ of the acid mixture [27].

\subsection{Synthesis of organic ligand (HL)}

The appropriate ethyl araylpyruvate $(1.08 \mathrm{~g}, 10 \mathrm{mmol})$ was added to $o$-phenylenediamine $(2.18 \mathrm{~g}, 10 \mathrm{mmol})$ in $25 \mathrm{~mL}$ ethanol and the mixture was heated under reflux for $2 \mathrm{~h}$ during which a crystalline precipitate was separated. After cooling, the product was filtered off, washed with alcohol and recrystallized from DMF/ethanol (1:3, v:v) [28].

\subsection{Synthesis of metal complexes}

The metal complexes were prepared by the addition of hot ethanolic solution $\left(60{ }^{\circ} \mathrm{C}, 10 \mathrm{~mL}\right)$ of the appropriate metal chloride $(1 \mathrm{mmol})$ to hot ethanolic solution $\left(60^{\circ} \mathrm{C}, 10 \mathrm{~mL}\right)$ of the organic ligand $(0.139 \mathrm{~g}, 1 \mathrm{mmol})$. The resulting mixture was stirred whereupon the complexes precipitated. They were collected by filtration, washed several times with ethanol and diethyl ether for further purification and dried under vacuum.

\subsection{Determination of the metal content of the chelates}

Metal contents were determined by titration against standard EDTA after complete decomposition of the complexes with aqua regia in a Kjeldahl flask, repeating several times $[27,29]$.

\subsection{Calculation of the metal complexes formation constants}

Chelate stability constants are obtained spectrophotometrically by measuring the absorbance of solutions of ligand and metal at fixed concentration but at distinct $\mathrm{pH}$ values ranging from 2 to 12 . The degree of formation of the complex is obtained from the relationship [30]:

$\mathrm{n}^{\sim}=\left(\mathrm{A}_{\mathrm{x}}-\mathrm{A}_{\mathrm{L}}\right) /\left(\mathrm{A}_{\mathrm{ML}}-\mathrm{A}_{\mathrm{L}}\right)$

where $A_{x}, A_{L}$ and $A_{m L}$ are the absorbances of the partially formed complex at a specific $\mathrm{pH}$, the free ligand and the fully formed complex, respectively. Then, the negative logarithm of the concentration of non-protonated ligand $(\mathrm{pL})$ was obtained using Eq. (2):

$\mathrm{pL}=\log \left[\left(1+\mathrm{B}_{1}{ }^{\mathrm{H}}\left[\mathrm{H}^{+}\right]+\mathrm{B}_{2}{ }^{\mathrm{H}}\left[\mathrm{H}^{+}\right]^{2+} \ldots\right) /\left(\mathrm{T}_{\mathrm{L}}-\mathrm{nT}_{\mathrm{M}}\right)\right]$

where $\mathrm{B}_{1} \mathrm{H}$ and $\mathrm{B}_{2} \mathrm{H}$ are the reciprocals of the acid dissociation constants of the ligand, i.e. $\left[\mathrm{LH}_{1}\right] /[\mathrm{L}][\mathrm{H}]$ and $\left[\mathrm{LH}_{2}\right] /[\mathrm{L}][\mathrm{H}]^{2}$, respectively. $\mathrm{T}_{\mathrm{L}}$ and $\mathrm{T}_{\mathrm{M}}$ represent the stoichiometric concentration of the ligand and metal, respectively. The stability constant (K) can be calculated from Eq. (3).

$\mathrm{n}^{\sim}+\left(\mathrm{n}^{\sim}-1\right) \mathrm{K}(\mathrm{L})=0$

\subsection{Biological activity}

The susceptible strain of locust, Schistocerca gregaria was obtained from Locust Research laboratory, Entomology Department, Faculty of Science, Cairo University. A stock colony was reared in cages $40 \times 50 \times 65 \mathrm{~cm}$. Except for the front side, which was made of glass; all the other three sides of the cages were made of wood, with a small window closed by wire gauze for ventilation. Each cage was supplied every morning with a suitable amount of fresh food, consisting of clover or maize leaves. The cages were provided with pots of moistened, sieved sand to serve as ovipositional sites.

The locust culture and the experimental tests, unless otherwise mentioned, were kept in a dark room where all windows were covered with thick black curtains. Light was provided by a set of 60 -watt electric bulbs. A bulb was hung in front of the glass side of each cage. All bulbs were connected to a time switch (a 24-hour automatic program timer) that would turn the lights on at 4.00 a.m. and off at 6.00 p.m., approximately corresponding to the times of sunrise and sunset in Egypt. Temperature in the cages was recorded to range between 30 and $35{ }^{\circ} \mathrm{C}$, while the relative humidity fluctuated between 60 and $80 \%$. 
Susceptible strain of Schistocerca gregaria was reared away from any insecticidal contamination. $5^{\text {th }}$ Nymphal instars of Schistocerca gregaria nymphs were treated with the novel chemicals of quinoxalin derivatives using topical treatment techniques according to the method of Nassar [31]. After preliminary test, three groups of $5^{\text {th }}$ nymphal instars $(5$ insects of each group) were received $2 \mu \mathrm{g} /$ insect of all testing compounds. Treatment was replicated three times, and not less than 15 insects were treated with each testing compound.

Starting with the day after treatment, all mortalities, malformation and adult longevities were recorded. Mortality \% was calculated for the next instars considering the initial number of treated hoppers, irrespective of the instars under test. All experiments were performed as triplicate and data plotted were the mean value.

\section{Results and discussion}

\subsection{Electron impact mass spectrum of organic ligand}

The electron impact mass spectrum of HL ligand is recorded and the important peaks and their relative intensities for the molecular ions are shown in Scheme 1. Mass spectrum of the studied organic ligand is characterized by moderate to high relative intensity molecular ion peaks. Scheme 1 shows a well-defined parent peak of $\mathrm{HL}$ at $\mathrm{m} / \mathrm{z}=278$ (R.I. $=49 \%$ ). Fragment at $\mathrm{m} / \mathrm{z}=93$ (R.I. $=100 \%$, base peak) is attributed to $\mathrm{C}_{6} \mathrm{H}_{7} \mathrm{~N}$ ion.
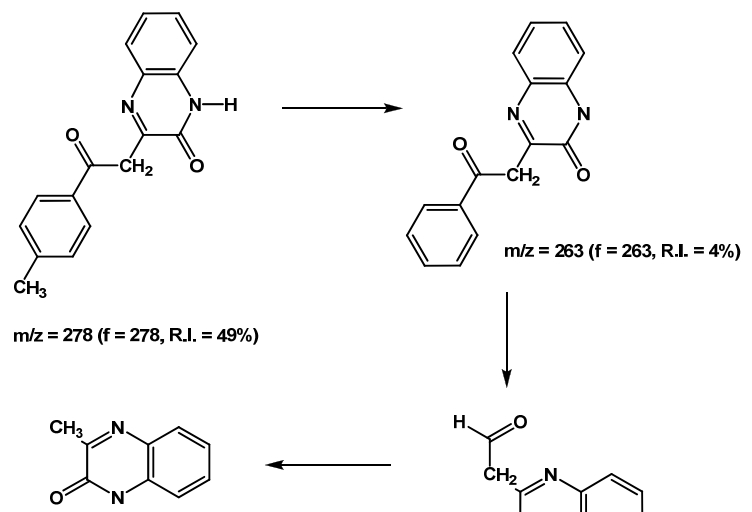

$m / z=159\left(f=159, R_{.} . .=23 \%\right)$

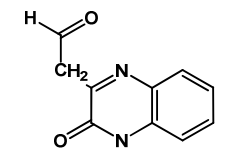

$m / z=187(f=187$, R.I. $=18 \%)$
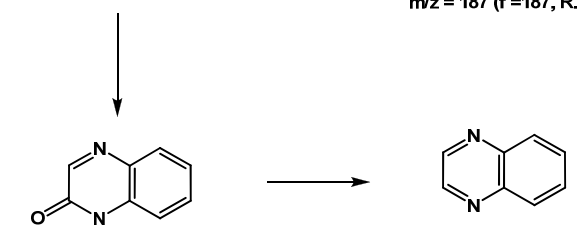

$m / z=144$ ( $f=145$, R.I. $=5 \%$ )

$m / z=128\left(f=130, R_{.} . .=9 \%\right)$

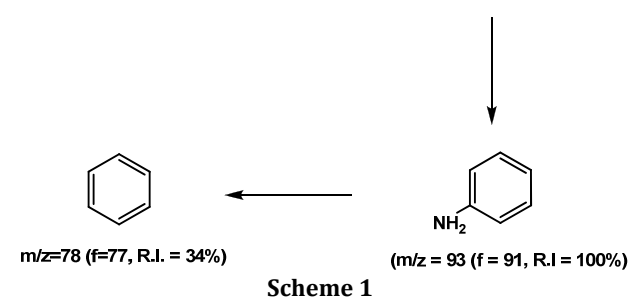

\subsection{Absorption spectra of organic ligand}

The absorption spectrum for $1 \times 10^{-4} \mathrm{M}$ solution of HL ligand under investigation in buffer solutions of varying $\mathrm{pH}$ values from 2-13 are scanned in the wavelength range from 200-700 $\mathrm{nm}$, against the same solvent as a blank. The absorption spectrum of HL ligand shows sharp bands at $420(\epsilon=1034$
L.mol $\left.{ }^{-1} \mathrm{~cm}^{-1}\right)$ and $430\left(\epsilon=1102\right.$ L.mol $\left.{ }^{-1} \mathrm{~cm}^{-1}\right)$. These bands can be attributed to $\pi-\pi^{*}$ and $n-\pi^{*}$ transitions within the organic ligand molecule.

\subsection{Ligands dissociation and metal-ligand stability constants}

The ligand dissociation constant was calculated by the half height method [32]. It is found that HL ligand is found to have two pKa values of 5.36 and 9.48, which can be attributed to the loss of the protonated $\mathrm{N}$ phenolic and keto-enol tautomeric $\mathrm{OH}$ groups, respectively. The free energy change, $\Delta \mathrm{G}^{\circ}$, was also calculated and found to be 348.4 and $466.8 \mathrm{~kJ} / \mathrm{mol}$ for the first and second ionizations, respectively. The negative values indicate the spontaneous character of the dissociation reaction.

The stability constants of Mn(II), Fe(III), Co(II), Ni(II), $\mathrm{Cu}(\mathrm{II})$ and $\mathrm{Zn}(\mathrm{II})$ complexes with the HL ligand are determined spectrophotometrically [30]. The mean $\log \beta_{1}$ and $\log \beta_{2}$ values are listed in Table 1 . The complex-forming abilities of the transition metal ions are frequently characterized by stability orders. The order of stability constants is found to be $\mathrm{Mn}^{2+}<$ $\mathrm{Co}^{2+}<\mathrm{Ni}^{2+}<\mathrm{Cu}^{2+}>\mathrm{Zn}^{2+}$ in accordance with the Irving and Williams order [33] for divalent metal ions of the $3 \mathrm{~d}$ series. It is clear from Table 1 that the stability of $\mathrm{Cu}(\mathrm{II})$ complexes are considerably larger as compared to other metals of the $3 \mathrm{~d}$ series. Under the influence of the ligand field, $\mathrm{Cu}(\mathrm{II})\left(3 \mathrm{~d}^{9}\right)$ will receive some extra stabilization [34] due to tetragonal distortion of octahedral symmetry in their complexes. The $\mathrm{Cu}(\mathrm{II})$ complexes will be further stabilized due to the JahnTellar effect [35]. The free energy of formation, $\Delta G^{\circ}$, accompanying the complexation reaction has been determined at $25{ }^{\circ} \mathrm{C}$ (Table 1). From the table, it is apparent that the negative values of $\Delta \mathrm{G}^{\text {o }}$ show that the driving tendency of the complexation reaction is from left to right and the reaction proceeds spontaneously.

Table 1. The calculated stability constants of the metal complexes.

$[\mathrm{HL}]=5 \times 10^{-4} \mathrm{M},[\mathrm{M}]=5 \times 10^{-4} \mathrm{M}, \lambda_{\max }=420 \mathrm{~nm}$.

\begin{tabular}{lcc}
\hline Complex & $\boldsymbol{l o g} \boldsymbol{\beta}_{\mathbf{1}}\left(-\mathbf{\Delta} \mathbf{G}_{\mathbf{1}}, \mathbf{k} \mathbf{j} / \mathbf{m o l}\right)$ & $\mathbf{L o g} \boldsymbol{\beta}_{\mathbf{2}}\left(\mathbf{- \Delta} \mathbf{\Delta \mathbf { o } _ { 2 }}, \mathbf{k J} / \mathbf{m o l}\right)$ \\
\hline$\left[\mathrm{Mn}(\mathrm{HL})_{2} \mathrm{Cl}_{2}\right]$ & $3.03(119)$ & $7.95(223)$ \\
{$\left[\mathrm{Fe}(\mathrm{HL})_{2} \mathrm{Cl}_{2}\right] \mathrm{Cl}$} & $4.06(150)$ & $9.20(239)$ \\
{$\left[\mathrm{Co}(\mathrm{HL})_{2} \mathrm{Cl}_{2}\right]$} & $4.08(151)$ & $9.31(240)$ \\
{$\left[\mathrm{Ni}(\mathrm{HL})_{2} \mathrm{Cl}_{2}\right]$} & $4.75(168)$ & $10.54(253)$ \\
{$\left[\mathrm{Cu}(\mathrm{HL})_{2} \mathrm{Cl}_{2}\right]$} & $5.18(154)$ & $10.75(245)$ \\
{$\left[\mathrm{Zn}(\mathrm{HL})_{2} \mathrm{Cl}_{2}\right]$} & $4.18(154)$ & $9.75(245)$ \\
\hline
\end{tabular}

\subsection{Elemental analyses of the complexes}

The results of elemental analyses are in good agreement with those required by the proposed formulae giving in Table 2 .

\subsection{Molar conductance measurements}

The chelates are dissolved in DMF and the molar conductivities of $10^{-3} \mathrm{M}$ of their solutions at $25 \pm 2{ }^{\circ} \mathrm{C}$ are measured. Table 2 shows the molar conductance values of the complexes. It is concluded from the results that the Co(II), $\mathrm{Ni}(\mathrm{II}), \mathrm{Cu}(\mathrm{II}), \mathrm{Zn}(\mathrm{II})$ and $\mathrm{Mn}(\mathrm{II})$ complexes have a molar conductivity values in the range of 7.58-9.68 $\Omega^{-1} \mathrm{~mol}^{-1} \mathrm{~cm}^{2}$ which indicates the non-ionic nature of these complexes and they are considered as non-electrolytes. Fe(III) complex is found to have a molar conductance value of $90.0 \Omega^{-1} \mathrm{~mol}^{-1} \mathrm{~cm}^{2}$, indicating its ionic nature and it is 1:1 electrolyte [37].

\section{6. ${ }^{1} \mathrm{H}$ NMR spectral studies}

The ${ }^{1} \mathrm{H}$ NMR spectra studies of the organic HL ligand and its $\mathrm{Zn}(\mathrm{II})$ complex is recorded in $d_{6}$-dimethylsulfoxide (DMSO- $d_{6}$ ) solution using tetramethylsilane (TMS) as internal standard. The chemical shifts of the different types of protons found in the ${ }^{1} \mathrm{H}$ NMR spectra of the organic ligand and its diamagnetic Zn(II) complex are listed in Table 3. 
Table 2. Analytical and physical data of HL ligand and its metal complexes.

\begin{tabular}{|c|c|c|c|c|c|c|c|c|c|}
\hline \multirow{2}{*}{ Compound } & \multirow{2}{*}{$\begin{array}{l}\text { Colour } \\
\text { (\% Yield) }\end{array}$} & \multirow{2}{*}{ M.p. $\left({ }^{\circ} \mathrm{C}\right)$} & \multicolumn{5}{|c|}{ \% Found (Calcd.) } & \multirow{2}{*}{$\begin{array}{c}\Lambda_{\mathrm{m}} \\
\Omega^{-1} \mathbf{m o l}^{-1} \mathbf{c m}^{2} \\
\end{array}$} & \multirow{2}{*}{$\begin{array}{c}\mu_{\text {eff. }} \\
\text { (B.M.) }\end{array}$} \\
\hline & & & C & $\mathbf{H}$ & $\mathbf{N}$ & M & Cl & & \\
\hline $\begin{array}{l}\mathrm{HL} \\
\mathrm{C}_{17} \mathrm{H}_{11} \mathrm{ClN}_{2} \mathrm{O}_{2}\end{array}$ & $\begin{array}{l}\text { Yellowish brown } \\
(60)\end{array}$ & 250 & $\begin{array}{c}73.38 \\
(73.20)\end{array}$ & $\begin{array}{c}5.04 \\
(5.07)\end{array}$ & $\begin{array}{c}10.07 \\
(10.15)\end{array}$ & ---- & ----- & ---- & ----- \\
\hline$\left[\mathrm{Mn}(\mathrm{HL})_{2} \mathrm{Cl}_{2}\right]$ & Reddish brown & & 59.82 & 4.11 & 4.21 & 8.09 & 10.41 & 7.69 & \\
\hline $\mathrm{C}_{34} \mathrm{H}_{22} \mathrm{Cl}_{4} \mathrm{MnN}_{4} \mathrm{O}_{4}$ & $(64)$ & 246 & (59.98) & $(4.09)$ & $(4.22)$ & $(8.06)$ & $(10.64)$ & & 5.95 \\
\hline$\left[\mathrm{Fe}(\mathrm{HL})_{2} \mathrm{Cl}_{2}\right] \mathrm{Cl}$ & Black & & 59.78 & 4.89 & 7.79 & 7.80 & 14.82 & & \\
\hline $\mathrm{C}_{34} \mathrm{H}_{22} \mathrm{Cl}_{5} \mathrm{FeN}_{4} \mathrm{O}_{4}$ & $(64)$ & 210 & (59.56) & $(4.78)$ & $(7.80)$ & $(7.79)$ & (14.41) & 90.00 & 5.59 \\
\hline$\left[\mathrm{Co}(\mathrm{HL})_{2} \mathrm{Cl}_{2}\right]$ & Pale green & 210 & 59.48 & 4.08 & 8.16 & 8.20 & 10.35 & 7.58 & 4.95 \\
\hline $\mathrm{C}_{34} \mathrm{H}_{22} \mathrm{Cl}_{4} \mathrm{CoN}_{4} \mathrm{O}_{4}$ & $(64)$ & & (59.31) & $(4.00)$ & $(8.71)$ & $(8.60)$ & $(11.10)$ & & \\
\hline$\left[\mathrm{Ni}(\mathrm{HL})_{2} \mathrm{Cl}_{2}\right]$ & Dark yellow & & 59.48 & 4.08 & 8.16 & 8.20 & 10.35 & & 293 \\
\hline $\mathrm{C}_{34} \mathrm{H}_{22} \mathrm{Cl}_{4} \mathrm{NiN}_{4} \mathrm{O}_{4}$ & $(64)$ & 244 & (59.53) & $(4.02)$ & (8.57) & $(8.60)$ & $(10.61)$ & 8.51 & 2.93 \\
\hline$\left[\mathrm{Cu}(\mathrm{HL})_{2} \mathrm{Cl}_{2}\right]$ & Brown & 210 & 59.09 & 4.06 & 8.11 & 9.80 & 10.28 & & \\
\hline $\mathrm{C}_{34} \mathrm{H}_{22} \mathrm{Cl}_{4} \mathrm{CuN}_{4} \mathrm{O}_{4}$ & $(64)$ & 210 & $(59.26)$ & $(4.22)$ & $(8.00)$ & $(9.20)$ & $(10.68)$ & 9.68 & 1.93 \\
\hline$\left[\mathrm{Zn}(\mathrm{HL})_{2} \mathrm{Cl}_{2}\right]$ & Yellowish brown & & 58.96 & 4.05 & 8.09 & 9.57 & 10.26 & & \\
\hline $\mathrm{C}_{34} \mathrm{H}_{22} \mathrm{Cl}_{4} \mathrm{~N}_{4} \mathrm{O}_{4} \mathrm{Zn}$ & (61) & 198 & (58.86) & $(4.06)$ & $(8.77)$ & $(9.39)$ & (10.61) & 9.37 & Diam. \\
\hline
\end{tabular}

The spectrum of the $\mathrm{Zn}$ (II) complex is examined in comparison with the parent organic ligand. Upon examinations it is found that the signals observed at $13.625 \mathrm{ppm}$ for HL ligand is assigned to $\mathrm{NH}$ proton. This signal is found at 13.626 ppm for its $\mathrm{Zn}$ (II) complex. This indicates the non participation of the $\mathrm{NH}$ group in chelation. This supports the findings suggested by the IR spectra. The small up field shift in the signal of -NH- proton may be attributed to the disruption of the intramolecular hydrogen bonding between the $-\mathrm{NH}$ proton and carbonyl oxygen during the complexation [16] or keto-enol formation.

Table 3. ${ }^{1 \mathrm{H}}$ NMR spectral data of the organic ligand and its metal chelates.

\begin{tabular}{lll}
\hline Compound & Chemical shift, $(\boldsymbol{\delta}) \mathbf{p p m}$ & Assignment \\
\hline \multirow{3}{*}{$\mathrm{HL}$} & 13.625 & $(\mathrm{~s}, 1 \mathrm{H}, \mathrm{NH})$ \\
& $7.820-6.794$ & $(\mathrm{~m}, 8 \mathrm{H}, \mathrm{Ar}-\mathrm{H})$ \\
& 3.319 & $(\mathrm{~s}, 3 \mathrm{H}, \mathrm{CH})$ \\
& 2.37 & $\left(\mathrm{~s}, 2 \mathrm{H}, \mathrm{CH}_{2}\right)$ \\
\hline & 13.626 & $(\mathrm{~s}, 2 \mathrm{H}, \mathrm{NH})$ \\
{$\left[\mathrm{Zn}(\mathrm{HL})_{2} \mathrm{Cl}_{2}\right]$} & $7.947-6.793$ & $(\mathrm{~m}, 16 \mathrm{H}, \mathrm{Ar}-\mathrm{H})$ \\
& 3.33 & $(\mathrm{~s}, 6 \mathrm{H}, \mathrm{CH})$ \\
& 2.376 & $\left(\mathrm{~m}, 4 \mathrm{H}, \mathrm{CH}_{2}\right)$ \\
\hline
\end{tabular}

\subsection{IR spectral studies}

The data of the IR spectra of the organic ligand and its complexes are listed in Table 4. The IR spectra of the complexes are compared with the free ligand in order to determine the coordination sites that may be involved in chelation. Upon comparison it is found that;

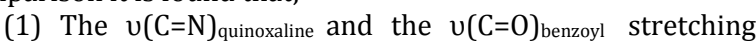
vibrations are found in the free HL ligand at 1606 and 1678 $\mathrm{cm}^{-1}$, respectively. These bands are shifted to higher or lower wavenumbers in the complexes to 1646-1659 and 1674-1675 $\mathrm{cm}^{-1}$ and disappeared, respectively, indicating the participation of the quinoxaline nitrogen and the benzoyl oxygen in coordination to the metal ions.

(2) The IR spectrum of the HL ligand shows the $v(\mathrm{NH})$ and

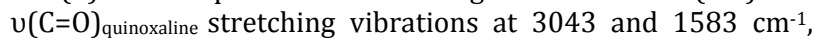
respectively. There is an upward and downward shift in these two bands (Table 4) although both quinoxaline 0 atom and primary amine $\mathrm{N}$ are not involved in the complexes formation. This is attributed to the cleavage of hydrogen bonding with the respective centers in the ligand during complexation [16].

Therefore, from the IR spectra, it is concluded that HL behaves as neutral bidentate ligand in all the complexes coordinating to the metal ions via quinoxaline $\mathrm{N}$ and benzoyl $\mathrm{O}$ atoms.

\subsection{Magnetic susceptibility and electronic spectral studies}

The diffused reflectance spectrum of the Mn(II) complex shows three bands at $15,470,21,660$ and $25,450 \mathrm{~cm}^{-1}$ assignable to ${ }^{6} \mathrm{~A}_{1 \mathrm{~g}} \rightarrow{ }^{4} \mathrm{~T}_{1 \mathrm{~g}}(\mathrm{G}),{ }^{6} \mathrm{~A}_{1 \mathrm{~g}} \rightarrow{ }^{4} \mathrm{~T}_{1 \mathrm{~g}}(\mathrm{P})$ and ${ }^{6} \mathrm{~A}_{1 \mathrm{~g}} \rightarrow{ }^{4} \mathrm{~T}_{1 \mathrm{~g}}(\mathrm{D})$ transitions, respectively $[37,38]$. The magnetic moment value is found to be 5.95 B.M. which indicates the presence of $\mathrm{Mn}$ (II) complex in octahedral structure [38]. The band observed at $28,240 \mathrm{~cm}^{-1}$ can be attributed to metal-to-ligand charge transfer transition. The observed magnetic moment value of Fe(III) complex is found to be 5.59 B.M., indicating octahedral geometry involving $\mathrm{d}^{2} \mathrm{sp}^{3}$ hybridization in Fe(III) ion [39,40]. From the diffused reflectance spectrum, it is observed that, the Fe(III) chelate exhibits bands at 15,145, 19,850 and 21,560 cm${ }^{1}$ which may be assigned to the ${ }^{6} \mathrm{~A}_{1 \mathrm{~g}} \rightarrow \mathrm{T}_{2 \mathrm{~g}}(\mathrm{G}),{ }^{6} \mathrm{~A}_{1 \mathrm{~g}} \rightarrow{ }^{4} \mathrm{~T}_{1 \mathrm{~g}}(\mathrm{D})$ and ${ }^{6} \mathrm{~A}_{1 \mathrm{~g}} \rightarrow{ }^{4} \mathrm{E}_{\mathrm{g}}(\mathrm{G})$ transitions in octahedral geometry of the complex $[39,40]$. The spectrum also shows a band at $23,740 \mathrm{~cm}^{-}$ ${ }^{1}$ which may be attributed to ligand to metal charge transfer.

The studied Ni(II) complex is high spin with a room temperature magnetic moment value of 2.93 B.M.; which is in the normal range observed for octahedral Ni(II) complexes [3940]. Its electronic spectrum displays three bands, in the solid reflectance spectra at $v_{1}:\left(12,390 \mathrm{~cm}^{-1}\right):{ }^{3} \mathrm{~A}_{2 \mathrm{~g}}(\mathrm{~F}) \rightarrow{ }^{3} \mathrm{~T}_{2 \mathrm{~g}}(\mathrm{~F}), v_{2}$ : $\left(14,780 \mathrm{~cm}^{-1}\right):{ }^{3} \mathrm{~A}_{2 \mathrm{~g}}(\mathrm{~F}) \rightarrow{ }^{3} \mathrm{~T}_{1 \mathrm{~g}}(\mathrm{~F})$ and $v_{3}:\left(20,888 \mathrm{~cm}^{-1}\right):{ }^{3} \mathrm{~A}_{2 \mathrm{~g}}(\mathrm{~F})$ $\rightarrow{ }^{3} \mathrm{~T}_{1 \mathrm{~g}}$ (P) $[38,40]$. The spectrum also shows a band at 25,333 $\mathrm{cm}^{-1}$ which may be attributed to ligand to metal charge transfer. The magnetic moment value of the Co(II) complex is found to be 4.95 B.M. which is indicative of octahedral geometry [43]. The electronic spectrum of the Co(II) complex gives three bands at $12,870,15,974$ and $21,208 \mathrm{~cm}^{-1}$. The region at 25,445 $\mathrm{cm}^{-1}$ refers to the charge transfer band. The bands observed are assigned to the transitions ${ }^{4} \mathrm{~T}_{1 \mathrm{~g}}(\mathrm{~F}) \rightarrow{ }^{4} \mathrm{~T}_{2 \mathrm{~g}}(\mathrm{~F})\left(\mathrm{v}_{1}\right),{ }^{4} \mathrm{~T}_{\mathrm{gg}}(\mathrm{F}) \rightarrow$ ${ }^{4} \mathrm{~A}_{2 \mathrm{~g}}(\mathrm{~F})\left(v_{2}\right)$ and ${ }^{4} \mathrm{~T}_{1 \mathrm{~g}}(\mathrm{~F}) \rightarrow{ }^{4} \mathrm{~T}_{1 \mathrm{~g}}(\mathrm{P})\left(v_{3}\right)$, respectively, suggesting that there is an octahedral geometry around Co(II) ion [38, 40, 42]. The magnetic moment of 1.93 B.M. indicates the octahedral geometry of the $\mathrm{Cu}$ (II) complex [39]. The reflectance spectrum of the $\mathrm{Cu}(\mathrm{II})$ chelate gives bands centered at 12,575, 17,640 and $23,445 \mathrm{~cm}^{-1}$. The ${ }^{2} \mathrm{E}_{\mathrm{g}}$ and ${ }^{2} \mathrm{~T}_{2 \mathrm{~g}}$ states of the octahedral $\mathrm{Cu}(\mathrm{II})$ ion $\left(d^{9}\right)$ split under the influence of the tetragonal distortion and the distortion can be such as to cause the three transitions ${ }^{2} \mathrm{~B}_{1 \mathrm{~g}}$ $\rightarrow{ }^{2} \mathrm{~B}_{2 \mathrm{~g}}$; ${ }^{2} \mathrm{~B}_{1 \mathrm{~g}} \rightarrow{ }^{2} \mathrm{E}_{\mathrm{g}}$ and ${ }^{2} \mathrm{~B}_{1 \mathrm{~g}} \rightarrow{ }^{2} \mathrm{~A}_{1 \mathrm{~g}}$ to remain unresolved in the spectrum [38]. This assignment is in agreement with the general observation that $\mathrm{Cu}(\mathrm{II}) d-d$ transitions are normally close in energy [39]. A moderately intense peak observed in the range $21,750 \mathrm{~cm}^{-1}$ is due to ligand to metal charge transfer transition [36,39]. The complex of $\mathrm{Zn}(\mathrm{II})$ is diamagnetic and according to the empirical formula an octahedral geometry is proposed for this complex.

\subsection{Thermal analyses (TG, DTG and DTA) studies}

Table 5 shows the TG, DTG and DTA results of the thermal decomposition of the chelates. The TG curve of the organic ligand exhibits the first estimated mass loss of 55.23\% (calcd. $55.04 \%$ ) within the temperature range from $225-450{ }^{\circ} \mathrm{C}$, which may be attributed to the liberation of $\mathrm{C}_{7} \mathrm{H}_{9} \mathrm{~N}_{2} \mathrm{O}_{2}$ molecule as gases. In the $2^{\text {nd }}$ stage within the temperature range of 450-700 ${ }^{\circ} \mathrm{C}, \mathrm{C}_{10} \mathrm{H}_{5}$ molecule losses with an estimated mass loss of $44.77 \%$ (calcd. $44.96 \%$ ). 
Table 4. IR data (4000-400 $\left.\mathrm{cm}^{-1}\right)$ of HL ligand and its metal complexes*.

\begin{tabular}{|c|c|c|c|c|c|c|}
\hline Compound & $v(\mathrm{NH})$ & $v(C=0)$ Benzoyl & $v(C=N)$ Quinoxaline & $v(C=0)$ Quinoxaline & $v(M-N)$ & $v(M-0)$ \\
\hline$\overline{\mathrm{HL}}$ & $3043 \mathrm{br}$ & $1678 \mathrm{sh}$ & $1606 \mathrm{sh}$ & $1583 \mathrm{sh}$ & ---- & $-\cdots$ \\
\hline$\left[\mathrm{Mn}(\mathrm{HL})_{2} \mathrm{Cl}_{2}\right]$ & $3060 \mathrm{br}$ & Disappeared & $1653 \mathrm{sh}$ & $1595 \mathrm{~s}$ & $530 s$ & $475 s$ \\
\hline$\left[\mathrm{Fe}(\mathrm{HL})_{2} \mathrm{Cl}_{2}\right] \mathrm{Cl}$ & $3059 \mathrm{br}$ & Disappeared & $1646 \mathrm{sh}$ & $1603 \mathrm{~m}$ & $566 s$ & $464 s$ \\
\hline$\left[\mathrm{Co}(\mathrm{HL})_{2} \mathrm{Cl}_{2}\right]$ & $3046 \mathrm{br}$ & $1674 \mathrm{sh}$ & $1653 \mathrm{~m}$ & $1607 \mathrm{~m}$ & $521 s$ & $462 s$ \\
\hline$\left[\mathrm{Ni}(\mathrm{HL})_{2} \mathrm{Cl}_{2}\right]$ & $3045 b r$ & $1675 \mathrm{~m}$ & $1650 \mathrm{~m}$ & $1609 \mathrm{~m}$ & $522 s$ & $462 s$ \\
\hline$\left[\mathrm{Cu}(\mathrm{HL}){ }_{2} \mathrm{Cl}_{2}\right]$ & $3050 \mathrm{br}$ & Disappeared & $1659 \mathrm{sh}$ & $1607 \mathrm{~m}$ & $527 w$ & $470 \mathrm{~s}$ \\
\hline$\left[\mathrm{Zn}(\mathrm{HL}){ }_{2} \mathrm{Cl}_{2}\right]$ & $3044 \mathrm{br}$ & Disappeared & $1656 \mathrm{sh}$ & $1609 \mathrm{~m}$ & $567 s$ & $460 s$ \\
\hline
\end{tabular}

* sh $=$ sharp, $\mathrm{m}=$ medium, br = broad, $\mathrm{s}=$ small, $\mathrm{w}=$ weak

\begin{tabular}{|c|c|c|c|c|c|c|c|}
\hline Compound & TG range $\left({ }^{\circ} \mathrm{C}\right)$ & $\operatorname{DTG}_{\max }\left({ }^{\circ} \mathrm{C}\right)$ & $n^{*}$ & $\begin{array}{l}\text { Mass Loss } \\
\text { Total mass Loss } \\
\text { Calcd. (Estim.) \% }\end{array}$ & Assignment & $\begin{array}{l}\text { Metallic } \\
\text { Residue }\end{array}$ & DTA $\left({ }^{\circ} \mathrm{C}\right)$ \\
\hline HL & $\begin{array}{l}225-450 \\
450-700\end{array}$ & $\begin{array}{l}343 \\
600\end{array}$ & $\begin{array}{l}1 \\
1\end{array}$ & $\begin{array}{l}55.04(55.23) \\
44.96(44.77) \\
100(100)\end{array}$ & $\begin{array}{l}\text {-Loss of } \mathrm{C}_{7} \mathrm{H}_{9} \mathrm{~N}_{2} \mathrm{O}_{2} \\
\text {-Loss of } \mathrm{C}_{10} \mathrm{H}_{5}\end{array}$ & - & $\begin{array}{l}252(+), 370(-) \\
580(-)\end{array}$ \\
\hline$\left.\left[\mathrm{Fe}(\mathrm{HL})_{2} \mathrm{Cl}_{2}\right)\right] \mathrm{Cl}$ & $\begin{array}{l}30-130 \\
130-380 \\
380-760\end{array}$ & $\begin{array}{l}58 \\
320 \\
608\end{array}$ & $\begin{array}{l}1 \\
1 \\
1\end{array}$ & $\begin{array}{l}10.16(9.13) \\
43.77(44.72) \\
35.21(35.41) \\
88.87(89.27)\end{array}$ & $\begin{array}{l}\text {-Loss of } 2 \mathrm{HCl} \\
\text {-Loss of } \mathrm{HCl} \text { and } \mathrm{HL} \\
\text {-Loss of } \mathrm{C}_{17} \mathrm{H}_{3} \mathrm{~N}_{2} \mathrm{O}_{0.5}\end{array}$ & $1 / 2 \mathrm{Fe}_{2} \mathrm{O}_{3}$ & $\begin{array}{l}50(-) \\
479(+), 510(-), 547(+) \\
625(-)\end{array}$ \\
\hline$\left.\left[\mathrm{Co}(\mathrm{HL})_{2} \mathrm{Cl}_{2}\right)\right]$ & $\begin{array}{l}25-120 \\
120-375 \\
375-750\end{array}$ & $\begin{array}{l}95 \\
210 \\
540\end{array}$ & $\begin{array}{l}1 \\
2 \\
1\end{array}$ & $\begin{array}{l}19.39(19.58) \\
17.64(17.93) \\
52.04(52.09) \\
89.07(89.6)\end{array}$ & $\begin{array}{l}\text {-Loss of } 2 \mathrm{HCl}, \mathrm{N}_{2} \mathrm{O} \text { and } \mathrm{CH}_{4} \\
\text {-Loss of } \mathrm{C}_{9} \mathrm{H}_{13} \\
\text {-Loss of } \mathrm{C}_{24} \mathrm{H}_{9} \mathrm{~N}_{2} \mathrm{O}_{2}\end{array}$ & $\mathrm{CoO}$ & $\begin{array}{l}67(+) \\
140(+), 420(+) \\
630(-)\end{array}$ \\
\hline$\left.\left[\mathrm{Ni}(\mathrm{HL})_{2} \mathrm{Cl}_{2}\right)\right]$ & $\begin{array}{l}30-120 \\
120-450 \\
450-600\end{array}$ & $\begin{array}{l}41,83 \\
252,340,428 \\
524\end{array}$ & $\begin{array}{l}2 \\
3 \\
1\end{array}$ & $\begin{array}{l}22.01(22.15) \\
40.52(41.89) \\
26.97(26.63) \\
89.07(90.66)\end{array}$ & $\begin{array}{l}\text {-Loss of } 2 \mathrm{HCl} \text { and } \mathrm{C}_{6} \mathrm{H}_{6} \\
\text {-Loss of } \mathrm{HL} \\
\text {-Loss of } \mathrm{C}_{11} \mathrm{H}_{6} \mathrm{~N}_{2} \mathrm{O}\end{array}$ & $\mathrm{NiO}$ & $\begin{array}{l}49(+), 87(+) \\
280(-), 320(+), 375(+), 452(+) \\
530(-)\end{array}$ \\
\hline
\end{tabular}

$\mathrm{n}^{*}=$ number of decomposition steps.

$(-)=$ Exothermic,$(+)=$ Endothermic

The DTA data presented in Table 5 show that the mass losses, as the result of the thermal decomposition of the ligand as gases, is appeared as endothermic peak at $252{ }^{\circ} \mathrm{C}$ and exothermic peaks at 370 and $580{ }^{\circ} \mathrm{C}$.

The TG curve of $\left.\left[\mathrm{Fe}(\mathrm{HL})_{2} \mathrm{Cl}_{2}\right)\right] \mathrm{Cl}$ chelate represents three decomposition steps as illustrated in Table 5. The first step of decomposition within the temperature range $30-130{ }^{\circ} \mathrm{C}$ corresponds to the loss of $2 \mathrm{HCl}$ gases with a mass loss of $9.13 \%$ (calcd. 10.16\%). The remaining steps of decomposition within the temperature range $130-760{ }^{\circ} \mathrm{C}$ correspond to the removal of the remaining ligand as gases. The overall weight losses amount to $88.26 \%$ (calcd. $88.86 \%$ ). Figure 1 b shows the DTA curve which shows three exothermic peaks at $(50,510$ and 625 ${ }^{\circ} \mathrm{C}$ ) and two endothermic peaks at (479 and $547{ }^{\circ} \mathrm{C}$ ). The appearance of many exothermic and endothermic peaks is due to the removal of the anions and ligand molecules as gases.

The Co(II) chelate is decomposed in four steps in the temperature range from $25-750{ }^{\circ} \mathrm{C}$. The first step is accounted to the loss of $2 \mathrm{HCl}, \mathrm{N}_{2} \mathrm{O}$ and $\mathrm{CH}_{4}$ molecules as gases with a mass loss of $19.58 \%$ (calcd. $19.39 \%$ ). The mass losses of the $2^{\text {nd }}$ and $3^{\text {rd }}$ steps $\left(\mathrm{T}=120-375{ }^{\circ} \mathrm{C}\right.$ ) correspond to the removal of $\mathrm{C}_{9} \mathrm{H}_{13}$ molecule and the ligand (estimated mass loss $=17.93 \%$; calcd. $=17.64 \%$ ). These steps are accompanied by exothermic peak $\left(630^{\circ} \mathrm{C}\right)$ and endothermic peaks $\left(67,140\right.$ and $\left.420^{\circ} \mathrm{C}\right)$. The final stage occurs within the temperature range from $375-750{ }^{\circ} \mathrm{C}$ and corresponds to the loss of $\mathrm{C}_{2} \mathrm{H}_{9} \mathrm{~N}_{2} \mathrm{O}_{2}$ molecule leaving metal oxide as a residue with a mass loss of $52.09 \%$ (calcd. 52.04. On the other hand, $\left[\mathrm{Ni}(\mathrm{HL})_{2} \mathrm{Cl}_{2}\right]$ chelate exhibits six decomposition steps within the temperature range from 30 $600{ }^{\circ} \mathrm{C}$. The estimated mass loss $=22.15 \%$ (calcd. $22.01 \%$ ) of the first step within the temperature range from $30-120{ }^{\circ} \mathrm{C}$ can be attributed to the loss of $2 \mathrm{HCl}$ and $\mathrm{C}_{6} \mathrm{H}_{6}$ molecules. According to the data listed in Table 5 , the total mass loss of the decomposition steps is found to be $91.64 \%$ (calcd. $89.10 \%$ ) and $\mathrm{NiO}$ is suggested as a residue. The DTA data are listed in Table 5. It is clear from these data that these mass losses have two exothermic (280 and $\left.530{ }^{\circ} \mathrm{C}\right)$ and five endothermic $(49,87$, 320,375 and $452^{\circ} \mathrm{C}$ ) peaks.

\subsection{Calculation of activation thermodynamic parameters}

The thermodynamic activation parameters of decomposition processes of dehydrated complexes namely activation energy $\left(E^{*}\right)$, enthalpy $\left(\Delta \mathrm{H}^{*}\right)$, entropy $\left(\Delta \mathrm{S}^{*}\right)$ and Gibbs free energy change of the decomposition $\left(\Delta G^{*}\right)$ are evaluated graphically by employing the Coats-Redfern relation [44]:

$$
\log \left[\frac{\log \left\{\mathrm{W}_{\mathrm{f}} /\left(\mathrm{W}_{\mathrm{f}}-\mathrm{W}\right)\right\}}{\mathrm{T}^{2}}\right]=\log \left[\frac{\mathrm{AR}}{\theta \mathrm{E}^{*}}\left(1-\frac{2 \mathrm{RT}}{\mathrm{E}^{*}}\right)\right]-\frac{\mathrm{E}^{*}}{2.303 \mathrm{RT}}
$$

Where $\mathrm{W}_{\mathrm{f}}$ is the mass loss at the completion of the reaction, $\mathrm{W}$ is the mass loss up to temperature T; R is the gas constant, $\mathrm{E}^{*}$ is the activation energy in $\mathrm{kJ} \cdot \mathrm{mol}^{-1}, \theta$ is the heating rate and (1$\left.\left(2 \mathrm{RT} / \mathrm{E}^{*}\right)\right) \cong 1$. A plot of the left-hand side of equation (4) against $1 / \mathrm{T}$ gives a slope from which $\mathrm{E}^{*}$ is calculated and $\mathrm{A}$ (Arrhenius factor) is determined from the intercept. The activation energies of decomposition are found to be in the range of 29.43-180.4 $\mathrm{kJ} \mathrm{mol}^{-1}$ (Table 6). The high values of the activation energies reflect the thermal stability of the complexes. The entropy of activation is found to have negative values in all the complexes which indicate that the decomposition reactions proceed with a lower rate than the normal.

\subsection{Structural interpretation}

On the basis of the above observations, the strucutres of the complexes are shown in Figure 2.

\subsection{Biological Activity}

The biological activities of HL and its metal complexes against the different developmental stages of the desert locust Schistocerca gregaria Forsk are studied. The data are listed in Table 7. On comparing the biological activity of the organic ligand and its metal complexes with specific control of only one biological function and not multiple ones, the following results are obtained: 
Table 6. Thermodynamic data of the thermal decomposition of HL and its metal complexes.

\begin{tabular}{|c|c|c|c|c|c|c|}
\hline Complex & Decomp. Temp. ${ }^{\circ} \mathrm{C}$ & $\mathrm{E}^{*}(\mathrm{~kJ} / \mathrm{mol})$ & $A\left(s^{-1}\right)$ & $\Delta S^{*}(\mathrm{~J} / \mathrm{molK})$ & $\Delta \mathbf{H}^{*}(\mathrm{~kJ} / \mathrm{mol})$ & $\Delta \mathrm{G}^{*}(\mathrm{~kJ} / \mathrm{mol})$ \\
\hline \multirow{2}{*}{ HL } & $225-450$ & 72.67 & $1.3 \times 10^{5}$ & -147.9 & 298.2 & 305.6 \\
\hline & $450-700$ & 82.20 & $7.7 \times 10^{5}$ & -137.7 & 373.6 & 257.5 \\
\hline \multirow{3}{*}{$\left[\mathrm{Fe}(\mathrm{HL})_{2} \mathrm{Cl}_{2}\right] \mathrm{Cl}$} & $30-130$ & 60.70 & $8.6 \times 10^{11}$ & -28.00 & 458.7 & 574.9 \\
\hline & $130-380$ & 29.43 & $2.8 \times 10^{7}$ & -83.80 & 267.7 & 335.8 \\
\hline & $380-760$ & 49.51 & $1.3 \times 10^{7}$ & -95.10 & 144.6 & 102.2 \\
\hline \multirow{4}{*}[\mathrm{Co}(\mathrm{HL})_{2}\mathrm{Cl}_{2}]{} & $25-120$ & 95.80 & $2.2 \times 10^{9}$ & -53.60 & 200.6 & 399.5 \\
\hline & $120-250$ & 35.92 & $1.5 \times 10^{10}$ & -43.20 & 243.6 & 344.7 \\
\hline & $250-375$ & 37.72 & $3.0 \times 10^{9}$ & -62.70 & 149.3 & 186.6 \\
\hline & $375-750$ & 81.16 & $2.7 \times 10^{6}$ & -128.10 & 358.5 & 157.6 \\
\hline \multirow{6}{*}[\mathrm{Ni}(\mathrm{HL})_{2}\mathrm{Cl}_{2}]{} & $30-57$ & 67.71 & $9.0 \times 10^{8}$ & -57.00 & 273.7 & 297.1 \\
\hline & $75-120$ & 180.4 & $7.5 \times 10^{7}$ & -83.50 & 173.6 & 242.9 \\
\hline & $120-315$ & 111.0 & $1.4 \times 10^{9}$ & -67.90 & 90.12 & 261.3 \\
\hline & $315-375$ & 57.56 & $2.6 \times 10^{9}$ & -65.70 & 292.7 & 252.7 \\
\hline & $375-450$ & 77.94 & $2.8 \times 10^{9}$ & -66.90 & 223.3 & 328.7 \\
\hline & $450-600$ & 98.02 & $3.9 \times 10^{4}$ & -142.5 & 336.6 & 168.3 \\
\hline
\end{tabular}

Table 7. Biological effect of HL and its metal complexes on the desert locust and adult longevities Schistocerca gregaria (Forsk.) (Orthoptera-Acrididae)*

\begin{tabular}{|c|c|c|c|c|c|c|c|}
\hline \multirow{2}{*}{$\begin{array}{l}\text { Dose of the } \\
\text { complexes } \\
2 \mu \mathrm{g} / \text { insect }\end{array}$} & \multicolumn{2}{|c|}{ \% Nymphal instar } & \multicolumn{3}{|c|}{$\%$ Adult stage } & \multicolumn{2}{|c|}{ Adult longevities Days \pm S.E. } \\
\hline & $\begin{array}{c}\text { Nymph } \\
\text { mortality }\end{array}$ & $\begin{array}{c}\text { Deformed } \\
\text { nymphs }\end{array}$ & $\begin{array}{c}\text { \% Emerged } \\
\text { adults }\end{array}$ & $\begin{array}{c}\text { \% Deformed } \\
\text { adults }\end{array}$ & $\begin{array}{c}\text { \% Normal } \\
\text { adults }\end{array}$ & Male & Female \\
\hline$\left[\mathrm{Mn}(\mathrm{HL})_{2} \mathrm{Cl}_{2}\right]$ & 60 & 27 & $87 \pm 4.4^{*}$ & $83 \pm 3.3^{*}$ & 5 & $87 \pm 4.4^{*}$ & $83 \pm 3.3^{*}$ \\
\hline$\left[\mathrm{Fe}(\mathrm{HL})_{2} \mathrm{Cl}_{2}\right] \mathrm{Cl}$ & 60 & 15 & $77 \pm 3.4^{*}$ & $75 \pm 4.2^{*}$ & 10 & $77 \pm 3.4 *$ & $75 \pm 4.2^{*}$ \\
\hline$\left[\mathrm{Co}(\mathrm{HL})_{2} \mathrm{Cl}_{2}\right]$ & 40 & 25 & $98 \pm 5.2(\mathrm{NS})$ & $94 \pm 4.2$ (NS) & 13 & $98 \pm 5.2(\mathrm{NS})$ & $94 \pm 4.2(\mathrm{NS})$ \\
\hline$\left[\mathrm{Ni}(\mathrm{HL})_{2} \mathrm{Cl}_{2}\right]$ & 100 & 00 & 00 & 00 & 00 & 00 & 00 \\
\hline$\left[\mathrm{Cu}(\mathrm{HL})_{2} \mathrm{Cl}_{2}\right]$ & 40 & 20 & $97 \pm 4.3(\mathrm{NS})$ & $91 \pm 4.2$ (NS) & 15 & $97 \pm 4.3(\mathrm{NS})$ & $91 \pm 4.2(\mathrm{NS})$ \\
\hline$\left[\mathrm{Zn}(\mathrm{HL})_{2} \mathrm{Cl}_{2}\right]$ & 60 & 18 & $88 \pm 5.2^{*}$ & $84 \pm 4.3^{*}$ & 12 & $88 \pm 5.2^{*}$ & $84 \pm 4.3^{*}$ \\
\hline Control & 00 & 00 & $129.2 \pm 5.2$ & $120.7 \pm 4.5$ & 98.8 & $129.2 \pm 5.2$ & $120.7 \pm 4.5$ \\
\hline
\end{tabular}

*: Significance at $\mathrm{P}<0.05$; (NS): Non significance at $\mathrm{P}<0.05$.

\subsubsection{Effect of quinoxaline ligand and its metal complexes on the 5th nymphal instars of Schistocerca gregaria}

The results of the effect of novel quinoxaline complexes on $5^{\text {th }}$ instars nymph of Schistocerca gregaria is recorded in Table 7. From the data recorded, it is observed that, treatment of newly ecdysed $5^{\text {th }}$ instar nymphs with the complexes is found to cause different mortality after $24 \mathrm{~h}$ post treatment. A complexes dependent mortality of Schistocerca gregaria can be easily observed in Table 7. Thus the highest mortality is found to be $100 \%$ which obtained after nymphal treatment with the [Ni(HL) ${ }_{2} \mathrm{Cl}_{2}$ ] complex. Meanwhile, $60 \%$ mortality is recorded after nymph treatment with the $\left[\mathrm{Mn}(\mathrm{HL})_{2} \mathrm{Cl}_{2}\right],\left[\mathrm{Fe}(\mathrm{HL})_{2} \mathrm{Cl}_{2}\right] \mathrm{Cl}$ and $\left[\mathrm{Zn}(\mathrm{HL})_{2} \mathrm{Cl}_{2}\right]$ complexes. On the other hand, a different nymphal deformation is obtained due to the effect of quinoxaline complexes against Schistocerca gregaria nymphs. The lowest deformation is $15 \%$ when nymph is treated with the $\left[\mathrm{Fe}(\mathrm{HL})_{2} \mathrm{Cl}_{2}\right] \mathrm{Cl}$ complex. The mortalities obtained reveal that many of adult deformations are inversely proportional with normal adults. The $\left[\mathrm{Mn}(\mathrm{HL})_{2} \mathrm{Cl}_{2}\right]$ complex is found to produce $83 \%$ of adult deformation, while the normal adult is $5 \%$.

In conclusion, the data obtained reveal that the $\left[\mathrm{Ni}(\mathrm{HL})_{2} \mathrm{Cl}_{2}\right]$ complex is the highest effective compound. A remarkable mortal potency of the studied organic compound and its complexes against the $5^{\text {th }}$ nymphal instar of the desert locust Schistocerca gregaria is estimated as compound dependent mortalities. This may explained by the inhibition of nymphal development induced by unbalance caused by the presence of chemicals in insect blood. These results suggest that quinoxaline complexes act directly on feeding inhibition. These compounds are found to play an important role in regulating activity and oviposition rhythm of locust Schistocerca gregaria.

\subsubsection{Effect different of quinoxaline ligand and its metal complexes on the adult longevity of Schistocerca gregaria}

Data listed in Table 7 reveal different varieties of adult longevity which emerged from treated $5^{\text {th }}$ nymphal instars of Schistocerca gregaria with the different complexes of quinoxaline where adult longevity depends on healthy immature stages. The male longevity is found to be more or less increased than the female longevity, i.e. the produced adult males are less sensitive than females. The higher male longevity is found to be non-significant $(\mathrm{P}>0.05)$ at 112 days and significance $(\mathrm{P}<0.05)$ at 66 days after nymphal treatment with the $\left[\mathrm{Co}(\mathrm{HL})_{2}\right] \mathrm{Cl}_{2}$ complex in comparison to 98 days of control male longevity. The same previous complex is found to cause no significance (110 days) and significance ( 94 days) of female longevity in comparison to 120 days of control female longevity (Table 7). These results agree with the application of different chemicals against locusts Schistocerca Gregaria [45].<smiles></smiles>

$M=M n(I I), C o(I I), N i(I I), C u(I I)$ and $Z n(I I)$<smiles></smiles>

Figure 2. Structural formulas of metal complexes. 


\section{References}

[1]. Veroni, I.; Mitsopoulou, C. A.; Lahoz, F. J. J. Organomet. Chem. 2008, 693, 2451-2457.

[2]. Nikam, S. S.; Cordon, J. J.; Ortwine, D. F.; Heimbach, T. H.; Blackburn, A. C.; Vartanian, M. G.; Nelson, C. B.; Schwarz, R. D.; Boxer, P. A.; Rafferty, M. F. J. Med. Chem. 1999, 42, 2266-2271.

[3]. Auberson, Y. P.; Acklin, P.; Allgeier, H.; Biollaz, M.; Bischoff, S.; Ofner, S.; Veenstra, S. J. Bioorg. Med. Chem. Lett. 1998, 8, 71-74.

[4]. Kim, K. S.; Qian, L. G.; Dickinson, K. E. J.; Delaney, C. L.; Bird, J. E.; Waldron, T. L.; Moreland, S. Bioorg. Med. Chem. Lett. 1993, 39, $2667-$ 2670.

[5]. Kim, K. S.; Qian, L. G.; Bird, J. E.; Dickinson, K. E. J.; Moreland, S.; Schaeffer, T. R.; Waldron, T. L.; Delaney, C. L.; Weller, H. N.; Miller, A. V. J. Med. Chem. 1993, 36, 2335-2342.

[6]. Melero, C. P.; Maya, A. B. S.; Rey, B. D.; Pelaez, R.; Caballero, E. Medarde, M. Bioorg. Med. Chem. Lett. 2004, 14, 3771-3774.

[7]. Piras, S.; Loriga, M.; Paglietti, G. Il Farmaco 2004, 59, 185-194.

[8]. Corona, P.; Vitale, G.; Loriga, M.; Paglietti, G. Molecules 2006, 11, 9981001.

[9]. Carta, A.; Loriga, M.; Zanetti, S.; Sechi, L. A. Il Farmaco 2003, 58, 1251 1255.

[10]. Hui, X.; Desrivot, J.; Bories, C.; Loiseau, P. M.; Franck, X.; Hocquemiller, R.; Figadere, B. Bioorg. Med. Chem. Lett. 2006, 16, 815-820.

[11]. Li, J.; Chen, J.; Zhang, L.; Wang, F.; Gui, C.; Zhang, L.; Qin, Y.; Xu, Q.; Liu, H.; Nan, F.; Shen, J.; Bai, D.; Chen, K.; Shen, X.; Jiang, H. Bioorg. Med. Chem. 2006, 14, 5527-5534.

[12]. Dianzhong, F.; Wang, M.; Wang, B. Polyhedron 1992, 11, 1109-1112.

[13]. Rani, D. S.; Lakshmi, P. V. A.; Jayatyagaraju, V. Trans. Met. Chem. 1994 19, $75-77$.

[14]. Sandhyarani, D.; Jayatyagaraju, V.; Ananthalakshmi, P. V. Indian J. Chem. 1999, 38A, 385-390.

[15]. Lakshmi, P. V. A.; Reddy, P. S.; Raju, V. J. Bull. Chem. Soc. Ethiop. 2008, 22, 385-390.

[16]. Lakshmi, P. V. A.; Reddy, P. S.; Raju, V. J. Spectrochim. Acta A 2009, 74, 52-57

[17]. Khan, S. A.; Saleem, K.; Khan, Z. Eur. J. Med. Chem. 2007, 42, 103-108.

[18]. Montoya, M. E.; Sainz, Y.; Ortega, M. A.; Ceráin, A. L.; Monge, A. Il Farmaco 1998, 53, 570-573.

[19]. Jaso, A.; Zarranz, B.; Aldana, I.; Monge, A. Eur. J. Med. Chem. 2003, 38, 791-800.

[20]. Vieites, M; Noblía, P.; Torre, M. H.; Cerecetto, H.; Lavaggi, M. L.; Filho, A. J. C.; Azqueta, A.; Cerain, A. L.; Monge, A.; Costa, B. P.; González, M.; Gambino, D. J. Inorg. Biochem. 2006, 100, 1358-1367.

[21]. Torre, M. H; Gambino, D.; Araujo, J.; Cerecetto, H.; González, M.; Lavaggi, M. L.; Azqueta, A.; Cerain, A. L.; Vega, A. M.; Abram, U.; Filho, A. J. C. Eur. J. Med. Chem. 2005, 40, 473-480.

[22]. Urquiola, C.; Gambino, D.; Cabrera, M.; Lavaggi, M. L.; Cerecetto, $\mathrm{H}_{\text {, }}$ González, M.; Cerain, A. L.; Monge, A.; Filho, A. J. C.; Torre, M. H. J. Inorg. Biochem. 2008, 102, 119-126.

[23]. Tarallo, M. B.; Urquiola, C.; Monge, A.; Pavan, F. R.; Leite, C. Q.; Torre, M. H.; Gambino, D. Met. Ions Biol. Med. 2008, 10, 865-872.

[24]. Tarallo, M. B.; Filho, A. J. C.; Vieira, E. D.; Monge, A.; Leite, C. Q.; Pavan, F. R.; Borthagaray, G.; Gambino, D.; Torre, M. H. J. Arg. Chem. Soc. 2009, 97, 80-89.

[25]. Urquiola, C.; Vieites, M.; Torre, M. H.; Cabrera, M.; Lavaggi, M. L.; Cerecetto, H.; González, M.; López de Cerain, A.; Monge, A.; Smircich, P.; Garat, B.; Gambino, D. Bioorg. Med. Chem. 2009, 17, 1623-1629.

[26]. Vogel, A. I. Quantitative Inorganic analysis Including Elemental Instrumental Analysis, 2nd Edition, Longmans, London, 1962.

[27]. Lurie J. Hand book of Analytical Chemistry, MIR Publisher, Moscow, 1975.

[28]. Andreichikov, Y. S.; Saraeva, R. F.; Fridman, A. L. Otkrytiya, Izobret., Prom. Obraztsy, Tovarnye znaki 1973, 50, 95-98; Chem. Abstract 1974, 81, 37577.

[29]. Mohamed, G. G.; El-Gamela N. E. A.; Teixidor, F. Polyhedron 2001, 20, 2689-3696

[30]. Anderson, R. G.; Nickless, G. Anal. Chim. Acta 1967, 39, 469-477.

[31]. Nassar, M. M. Proceeding of 3rd conference of applied entomology, pp. 279-294, 2005.

[32]. Issa, I. M.; Issa, R. M.; Mahmoud, M. R.; Temerk, Y. M. Z. Physik. Chem. 1973, 254, 314-318

[33]. Irving, H.; Williams, R. J. P. J. Chem. Soc. 1983, 3192-3210.

[34]. Olie, G. H.; Olive, S. The Chemistry of the Catalyzes Hydrogenation of Carbon Monoxide, Springer, Berlin, pp. 152, 1984.

[35]. Orgel, L. E. An Introduction to transition Metal Chemistry Ligand Field Theory, Methuen, pp. 55, 1966

[36]. Mohamed, G. G.; El-Gamel, N. E. A. Spectrochim. Acta A 2004, 60, 3141 3151.

[37]. Sanmartin, J.; Bermejo, M. R.; Deibe, A. M. G.; Maneiro, M.; Lage, C.; Filho, A. J. C. Polyhedron 2000, 19, 185-192.

[38]. Refat, M. S.; Chandra, S.; Tyagi, M. J. Therm. Anal. Calorim. 2010, 100, 261-267.

[39]. Cotton, F. A.; Wilkinson, G.; Murillo, C. A.; Bochmann, M. Advanced Inorganic Chemistry, $6^{\text {th }}$ edn.; Wiley, New York, 1999.
[40]. G. G. Mohamed, G. G.; M. A. Zayed, M. A.; N. E. A. El-Gamel, N. E. A. Spectrosc. Lett. 2000, 33, 821-832.

[41]. Ali, M. A.; Majumder, S. M. M. H.; Butcher, R. J.; Jasinski, J. P.; Jasinski, J. M. Polyhedron 1997, 16, 2749-2754.

[42]. Prasad, R.; Thankachan, P. P.; Thomas, M. T.; Pathak, R. J. Ind. Chem. Soc. 2001, 78, 28-31.

[43]. Mondal, N.; Dey, D. K.; Mitra, S.; Abdul Malik, K. M. Polyhedron 2000 19, 2707-2711.

[44]. Coats, A. W.; Redfern, J. P. Nature 1964, 201, 68-69.

[45]. Bullerjahn, A. M.; Pfluger, H. J. T.; Stevenson, P. A. Cell Tissue Res. 2006, 325, 345-360. 